\title{
Redescription and taxonomic validity of Leptodiaptomus cuauhtemoci (Osorio- Tafall, 1941) (Copepoda, Calanoida), with notes on its known distribution
}

\author{
Eduardo SUÁREZ-MORALES*, Marcelo SILVA-BRIANO ${ }^{1)}$ and Manuel ELÍAS-GUTIÉRREZ \\ El Colegio de la Frontera Sur (ECOSUR)-Chetumal A.P. 424. Chetumal, Quintana Roo 77000, Mexico \\ ${ }^{1)}$ Universidad Autónoma de Aguascalientes. Centro de Ciencias Básicas. Depto. de Biología. Av. Universidad 940. Fracc. Primo \\ Verdad, Aguascalientes 20100, Mexico \\ *e-mail corresponding author: esuarez@ecosur-qroo.mx
}

\begin{abstract}
Within the American freshwater calanoid copepods, Leptodiaptomus includes species whose taxonomical status is still unclear. One of them is L. cuauhtemoci (Osorio-Tafall), for decades considered to be a synonym of $\mathrm{L}$. siciloides (Lilljeborg); another species involved in this problem is $\mathrm{L}$. assiniboiensis (Anderson \& Fabris) described from Canada, which had been found to be closely related to L. cuauhtemoci. This species remained of uncertain taxonomy because the type material was lost decades ago. In order to disentangle this controversy, type specimens of L. assiniboiensis, topotypic specimens of $\mathrm{L}$. cuauhtemoci from a National Park in central Mexico, and confirmed specimens of $\mathrm{L}$. siciloides from different locations in Mexico and the United States were used to define the status of these species. Leptodiaptomus cuauhtemoci was fully redescribed using SEM. Based on the main characters used to differentiate species of Diaptomidae, L. assiniboiensis (= Diaptomus intermedius Anderson \& Fabris) turned out to be conspecific and a junior synonym of L. cuauhtemoci, which then becomes the valid name. The latter species shows taxonomically relevant differences with respect to L. siciloides. In the females the main differences is that the lateral spiniform processes on the genital somite are broader-based in L. cuauhtemoci, the genital field is different in both species. In L. cuauhtemoci the fifth leg endopods bear two large, broad, subterminal setae of about the same size, differently built than in $\mathrm{L}$. siciloides. The male L. cuauhtemoci is slenderer, with wings of pediger 5 clearly more developed than those of $\mathrm{L}$. siciloides. The armature of the modified right antennules and the structure of the fifth leg differ in both species. A large coxal spine is present on the right fifth leg of L. siciloides, whereas it is absent in L. cuauhtemoci. These differences were considered to be enough evidence for recognizing L. cuauhtemoci as a separate, valid species. Topotypic specimens of $\mathrm{L}$. cuauhtemoci are designated as neotypes.
\end{abstract}

Key words: Copepoda, Leptodiaptomus, taxonomy, distribution

\section{INTRODUCTION}

The genus Leptodiaptomus, as described by Light, 1938 comprises small or medium-sized diaptomid copepods characterized mainly by a left male and both female antennules with only one seta on segment 11 , a very reduced female fifth leg terminal exopodite (represented only by a small spine and a short seta near the spine of the second exopodal segment), and a right male antennule with strong spines on segments 10,11 and 13 (Wilson 1954; Dussart \& Defaye 1995; Suárez-Morales et al. 1996).

Up to seven species of this genus have been hitherto recorded in Mexico, they are distributed in several states: Leptodiaptomus novamexicanus (Herrick 1895) in Yucatan, Puebla, and Campeche; L. mexicanus (Marsh 1929) in Mexico City and the state of Mexico, L. siciloides (Lilljeborg 1889) in Aguascalientes and Coahuila, L. connexus (Light 1938) in Coahuila, L. assiniboiensis (Anderson) in Mexico City, L. cuauhtemoci (Osorio-Tafall 1941) in Morelos, and quite recently, $L$. dodsoni Elías-Gutiérrez, Romano \& Suárez-Morales in Jalisco and Michoacán (Reid 1990; Grimaldo-Ortega et al. 1998; Suárez-Morales et al. 1996; Suárez-Morales \& Reid 1998; Elías-Gutiérrez et al. 1999).
The identity of Leptodiaptomus cuauhtemoci has been questioned by different authors (Wilson \& Yeatman 1959; Balcer et al. 1984; Reid 1990), who considered this species to be a synonym of $L$. siciloides. However, this purported synonymy has not been supported or discarded through examination of biological material. There is another nominal species involved in this taxonomical confusion: L. assiniboiensis. It was described from Canada as a form very closely related to $L$. siciloides (Anderson \& Fabris 1970); it is also related to $L$. cuauhtemoci. Grimaldo-Ortega et al. (1998) recognized it in central Mexico and presented some illustrations.

On the other hand, all the type specimens upon which L. cuauhtemoci was originally described (males and females from Compila lagoon, Zempoala Lagoon system, state of Morelos, central Mexico), were deposited decades ago in the collection of the Escuela Nacional de Ciencias Biológicas (ENCB-IPN), Mexico (Osorio-Tafall 1941), but were lost together with most Osorio-Tafall's material several years ago. The species had not been recorded again since it was first described and its taxonomic status became even more obscure.

Recent collections of zooplankton in Aguascalientes, central Mexico, yielded several specimens of diaptomid copepods assignable to $L$. cuauhtemoci (Silva-Briano \& 
Suárez-Morales 1998). However, in order to perform a redescription of this species and review its taxonomical status, it was mandatory to survey the type locality (Compila lagoon) and look for this population of $L$. cuauhtemoci. We did this recently and our zooplankton samples contained several specimens belonging to this species.

In this work we redescribe Leptodiaptomus cuauhtemoci from the material collected in the type locality, designate the species neotypes, and provide morphological data to support the recognition of L. cuauhtemoci as a separate species by comparing it with its closest known related species, $L$. siciloides, of which it is a presumed synonym, and with L. assiniboiensis.

\section{METHODS}

Adult specimens of Leptodiaptomus cuauhtemoci were collected during a limnological survey of the Compila lagoon, in the hydrological system of the Parque Nacional Lagunas de Zempoala, state of Morelos, central Mexico. This park is currently under federal protection by the Mexican government. Additional $L$. cuauhtemoci and L. siciloides material was also collected during zooplankton surveys in several ponds in the state of Aguascalientes, central Mexico (see SilvaBriano \& Suárez-Morales 1998). In both cases, zooplankton samples were collected using standard plankton nets with $0.050-0.054 \mathrm{~mm}$-sized meshes. The material was fixed in $5-6 \%$ formaline solution. Copepods were sorted from the entire sample and preserved in $70 \%$ ethanol. Male and female specimens of each species were then processed for examination with a Topcon Scanning Electronic Microscope (SEM). All observations were made at 10-15 kV. Descriptions were based both, on SEM micrographs and on direct observations of specimens dissected in glycerin and drawn under a camera lucida.

\section{MATERIAL EXAMINED}

Leptodiaptomus cuauhtemoci. Several adult males and females, Compila lagoon, Morelos, Mexico.

Neotype: adult male, collected by Manuel Elías-Gutiérrez, 21 December 21, 1997 deposited at the National Museum of Natural History, Smithsonian Institution, catalogue number USNM-288074. One adult female, same locality (USNM-288075). Three adult males (USNM-288076) and four adult females (USNM288077), same locality and date, deposited at the National Museum of Natural History, Smithsonian Institution. Three adult males and three adult females, same locality, deposited in the Zooplankton collection of ECOSUR, in Chetumal, Mexico (ECO-CHZ-00509, 00510). Additional material and original samples at ECOSUR, Chetumal, Mexico. Leptodiaptomus siciloides. Several adult males and females identified (as Diaptomus siciloides) by M.S. Wilson. Labeled as col- lected in dam at mental hospital, Weyburn, USA. June 21, 1949 (USNM 210797). Several adult females and males from Campbell County, Thunder Basin, and Prairie Pond, Wyoming, USA. (USNM 259932). Several adult males and females, P. Elías Calles Dam, Aguascalientes, México (USNM 250290). Leptodiaptomus assiniboiensis (= Diaptomus intermedius Anderson \& Fabris). Adult males and female paratype specimens, Saskatchewan, Canada. (USNM 128137).

\section{RESULTS}

Leptodiaptomus cuauhtemoci (Osorio-Tafall 1941) Diaptomus intermedius Anderson \& Fabris 1970: 49, Figs 1-12.

Leptodiaptomus assiniboiensis (Anderson, 1971): 133.

Leptodiaptomus assiniboiensis.- Grimaldo-Ortega et al. 1998: 383, Figs 14-21.

Leptodiaptomus assiniboiensis.- Suárez-Morales \& Reid 1998: 258

\subsection{Species description}

\subsubsection{Female}

Length, mean $=1.23 \mathrm{~mm}$, range $=1.00-1.32 \mathrm{~mm}(\mathrm{~N}$ =12). Rostral points strong, acute (Fig. 14). Body (Fig. 2 ): prosome relatively wide, symmetrical, slighty constricted posterior to cephalic region. Thoracic wings asymmetrical, left wing with one short and robust spine located on lateral posterior margin, and one small spine on middle portion of posterior margin. Right wing larger than left, with terminal rounded spine, posterior margin straight, wide. Urosome with three somites, relative lengths of each being: 42.7:24.3:33=100. Genital double somite assymetrical, about 1.3 times as long as the remaining urosomal somites together, with lateral wing-like projections each tipped with short, robust spine, left projection relatively lower and larger than right, both pointing laterally. Genital somite ventrally expanded, genital opening with proximal margin rounded, with two rounded lappets on upper right and left portions of genital opening (Fig. 23); posterior margin of somite slender. Postgenital somite relatively short, naked. Anal somite large. Caudal rami about twice as long as wide, lightly haired along inner margin. Five caudal setae plumose, non-articulated, relatively short, about 2.5 times the length of caudal rami. Dorsal seta long, about 1.5 times length of rami.

Antennules long (Fig. 3), reaching beyond posterior margin of caudal rami by 2-3 segments. Segments 1-8 and 9 each with few tiny hairs irregularly scattered on posterior surface. Seta on segment 1 short, reaching midlength of segment 2. Appendages per segment as follows $($ Roman numerals $=$ segment, Arabic numerals $=$ number of setae, $\mathrm{a}=$ aesthetasc, $\mathrm{sp}=$ spine $)$ : $\mathrm{I}(1+\mathrm{a})$, $\mathrm{II}(3+\mathrm{a}), \operatorname{III}(1), \operatorname{IV}(1), \mathrm{V}(1), \mathrm{VI}(1+\mathrm{a}), \mathrm{VII}(1+\mathrm{a}), \mathrm{VIII}(2)$, IX(2+a), X(1), XI(1), XII(1+a), XIII-XIX(1), XX(1+a), XXI(1), XXII(2), XXIII(1), XXIV (2), XXV(4+a). 
Second antenna, Maxillule, maxilla and maxilliped similar in structure to those described for L. dodsoni Elías-Gutiérrez, Suárez-Morales \& Romano, 1999.

Mandible (Fig. 5) with 6 or 7 teeth on gnathobase, short dorsal seta on distal margin. Distal end of inner margin with short setulated seta-like projection. Basis with 4 setae; endopod with 2 segments, proximal segment with two setae; distal segment longer and narrower, with 5 setae. Exopod 3-segmented, with 1, 1, 3 setation pattern.

First leg (Fig. 7) relatively small, with 3-segmented exopod, and 2-segmented endopod, coxa with row of short setules along inner margin; plumose seta on same margin, reaching midlength of second endopodal segment. Basis with row of setules along external margin. Second, third and fourth legs with exopods and endopods 3-segmented (Figs 8-10). Armature formula for swimming legs:

\begin{tabular}{lcccc}
\hline & coxa & basis & exopod & endopod \\
\hline leg 1 & $0-1$ & $0-0$ & $\mathrm{I}-1 ; 0-1 ; \mathrm{I}, 3,2$ & $0-1 ; 1,2,3$ \\
leg 2 & $0-1$ & $0-0$ & $\mathrm{I}-1 ; \mathrm{I}-1 ; \mathrm{I}, 3,3$ & $0-1 ; 0-2 ; 2,2,3$ \\
leg 3 & $0-1$ & $0-0$ & $\mathrm{I}-1 ; \mathrm{I}-1 ; \mathrm{I}, 3,3$ & $0-1 ; 0-2 ; 2,2,3$ \\
leg 4 & $0-1$ & $0-0$ & $\mathrm{I}-1 ; \mathrm{I}-1 ; \mathrm{I}, 3,3$ & $0-1 ; 0-2 ; 2,2,3$ \\
\hline
\end{tabular}

Leg 5 (Figs 12, 22): Coxa with right coxal spine reaching proximal margin of first exopodal segment; left coxal spine barely reaching distal end of basis. Basis with inner margin widely rounded, lateral sensory seta reaching 1/2 of length of exopod 1. Endopod one-segmented, reaching beyond anterior margin of first exopodal segment, tip protruding in relatively acute process, covered by short setules. Two large, thick endopodal subterminal spines. Exopod 1 about as long as exopod 2 , with smooth, straight margins. Inner margin of exopod 2 claw armed with short row of low teeth on middle margin. Exopod 3 very reduced, barely distinct from exopod 2, represented by short, strong, spiniform process, accompanied by the usual spine near the base of exopod 3. Both structures subequal in length and breadth (Fig. 22).

\subsubsection{Male}

Length, mean $=1.13 \mathrm{~mm}$, range $=1.06-1.24 \mathrm{~mm}(\mathrm{~N}$ $=18$ ). Body slender (Fig. 1), with a typically diaptomid shape. Pedigers 4 and 5 almost of the same width. Pediger 5 (sixth thoracic somite) with lateral "wings" asymmetrical, less developed than in female, each with one short, blunt spine. Right wing relatively wider, pointing outwards, with straight posterior margin. Left wing end pointing posteriorly, with small terminal spiniform process. Urosome symmetrical, five-segmented, relative lengths of urosomal somites being:

$$
17.2: 29: 20.5: 20.5: 12.8=100 \text {. }
$$

Urosomite 1 (genital somite) asymmetrical, anterior half of left lateral margin slightly protuberant. Anterior right half with a small protuberance bearing a small spinule, slightly directed backwards. Urosomite 1,2 and 3 with several groups of spinules, each decreasing in size, along dorsal posterior margin. Caudal rami as described for the female. Inner margins of caudal rami lightly plumose. Rostral points short, thick and more or less blunt (Fig. 13).

Antennules relatively shorter than in female, last antennular segment almost reaching posterior margin of caudal rami. Segments 10-21 of right antennule modified, geniculation between segments 17-18 (Figs 4, 1517). Right antennule with one seta on segments $2-6$, and one aesthetasc on segments 1, 3, 5, 9 and 12; one large seta on segment 7, and one smaller on segment 8; 9 with one seta; 10 and 11 each with one stout spine reaching middle portion of next segment (Fig. 15); 12 with one seta; segment 13 with one seta and a long spine; 14 with one long and one short seta; 17 and 18 each with paired spiniform acute processes pointing distally (Fig. 16); antepenultimate segment with curved spiniform process reaching halfway the penultimate segment (Fig. 17). Terminal segment short, with 4 setae. Setation of left antennule as in female. Antennae and other cephalic appendages as in female.

Left leg 5 (Figs 11, 18) almost reaching proximal fourth of inner margin of right second exopodal segment. Coxa with no particular ornamentation. Basis with lateral seta reaching well beyond distal margin of bearing segment. First exopodal segment about 1.3 times longer than segment 2, with tuft of short setules on distal inner margin. Second exopodal segment ending in distal process with a stout, blunt, smooth terminal spiniform structure. Inner margin of exopod 2 with one low rounded process, haired on proximal half, with small vesicle-like processes on distal half (Fig. 18). Endopod slender, reaching beyond $2 / 3$ of exopod 2 , one-segmented, narrowing at distal third, tip blunt.

Right leg (Figs 11, 19-21): coxa with outer margin rounded. Basis with outer lateral seta, inserted about $2 / 3$ of lateral margin, not reaching or reaching slightly beyond distal end of same segment; basis twice as long as succeeding first exopodal segment. Outer margin of exopod 1 straight and slender, inner margin with a high, bilobulated anvil-shaped longitudinal hyaline process (Fig. 20). Exopod 2 slightly less than 2.5 times length of exopod 1. Lateral spine borne at midlength of segment about as thick as endopod and about the same length as exopod 1, moderately to strongly curved, naked, distal end blunt, rounded (Fig. 21). Terminal claw relatively strong, curved, broad-based, tapering gradually from thick proximal third, about 1.6 times longer than exopods 1 and 2 combined, without teeth on inner margin, but with naked lamellar hyaline process from midlength of inner margin to the tip (Fig. 21). Right endopod reaching slightly beyond distal margin of first exopodal segment, tapering to blunt point (Fig. 19) with patch of short hair-like setae on inner margin, from middle portion to distal end (Fig. 19). 


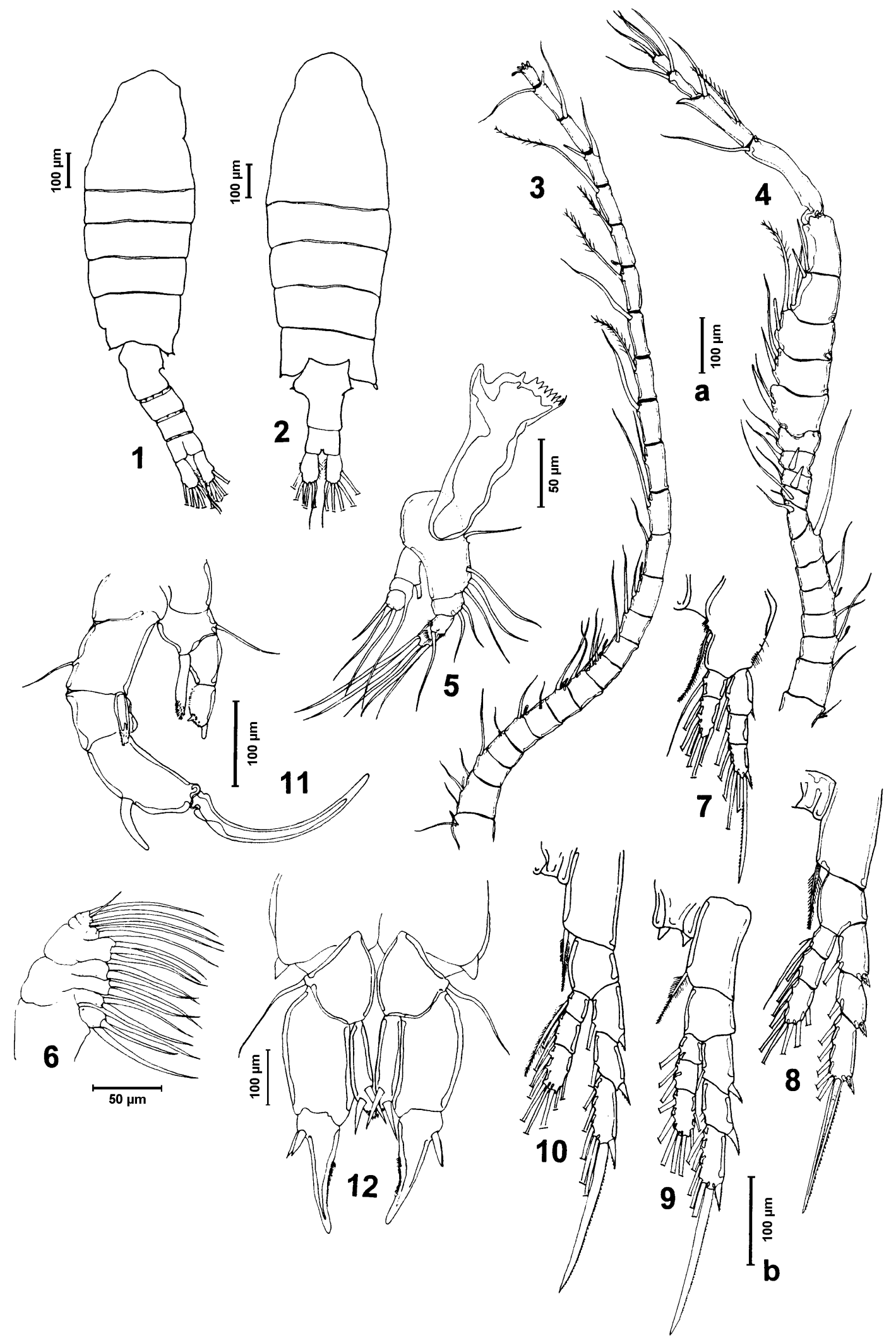

Figs 1-12. Leptodiaptomus cuauhtemoci; explanation in the text. 

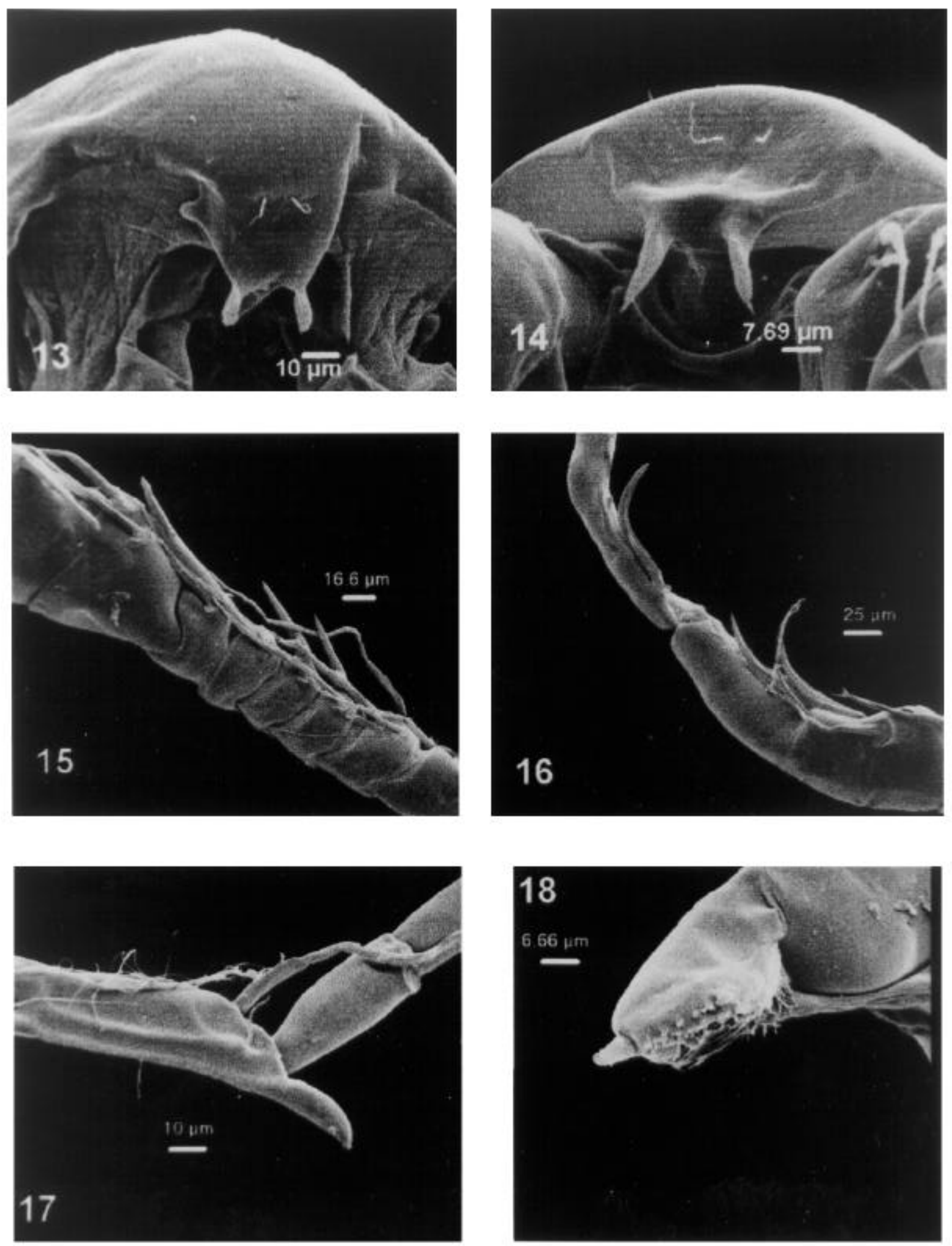

Figs 13-18. Leptodiaptomus cuauhtemoci; explanation in the text. 

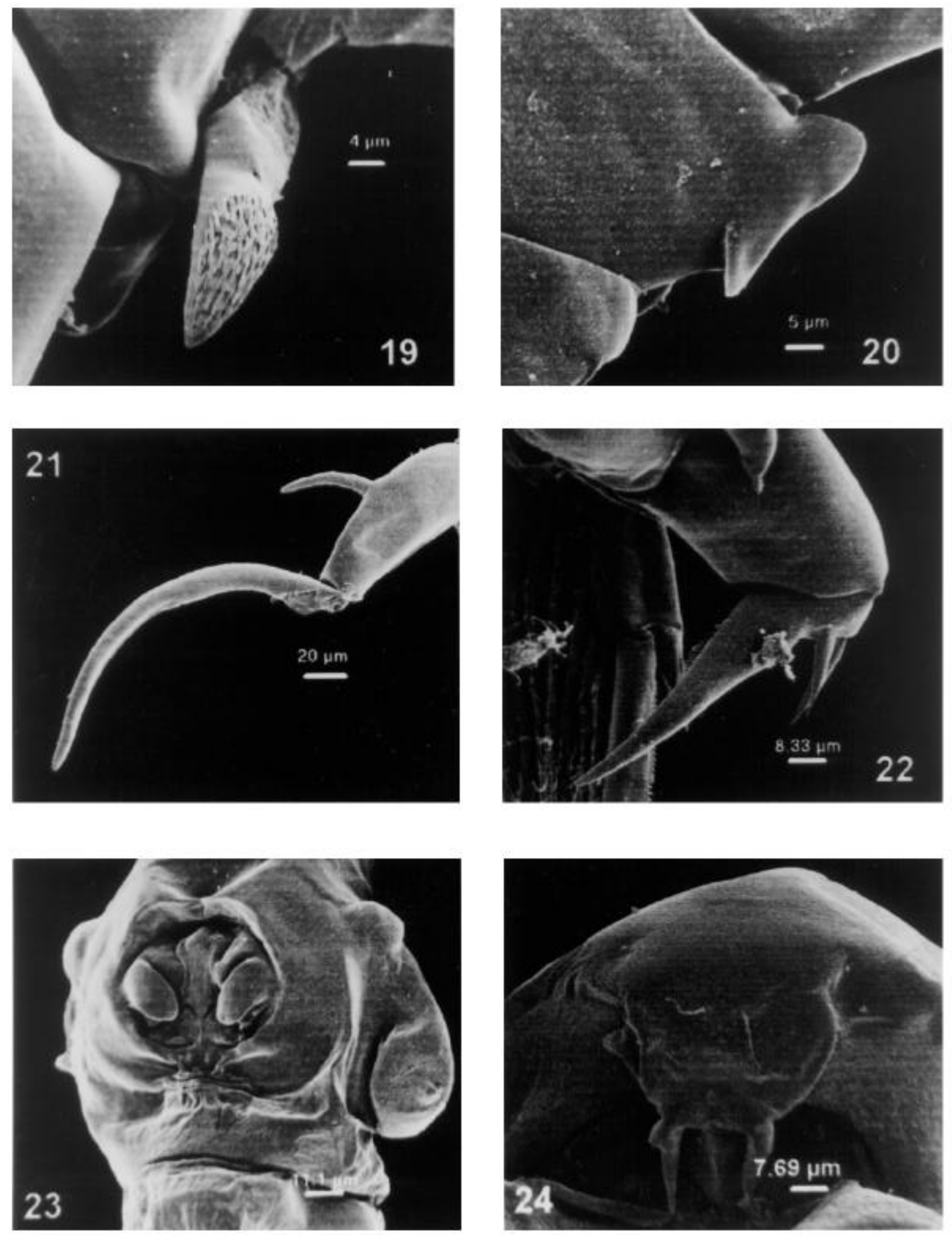

Figs 19-24. Leptodiaptomus cuauhtemoci; explanation in the text. 

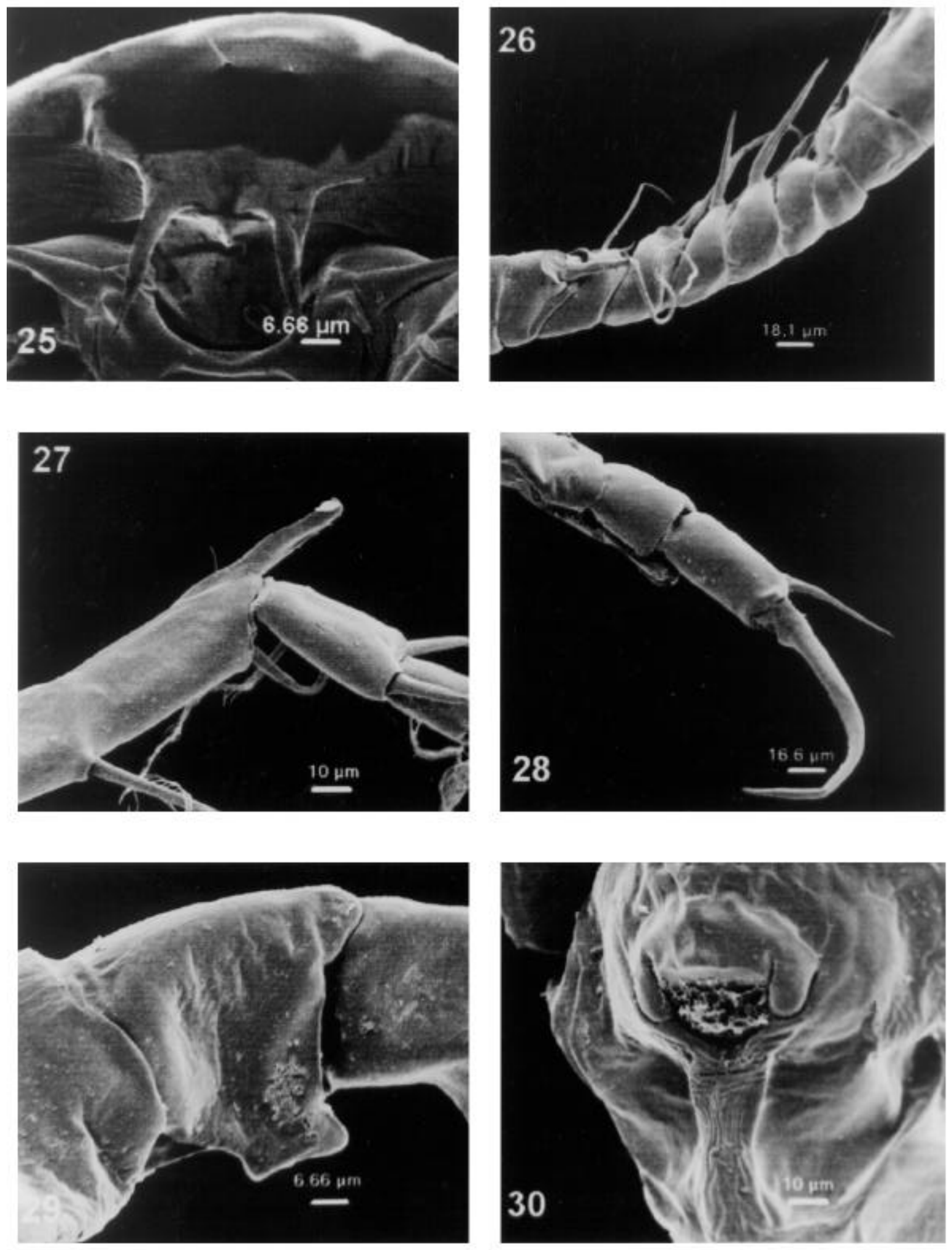

Figs 25-30. Leptodiaptomus cuauhtemoci; explanation in the text. 


\subsection{Type locality}

Although a neotype is designated here, the type locality remains the same as that associated with the original description of L. cuauhtemoci. The Compila lagoon belongs to the Zempoala lagoon system, in the State of Morelos about $17 \mathrm{~km}$ north of Cuernavaca city $\left(19^{\circ} 15^{\prime} 30^{\prime \prime} \mathrm{N}, 9^{\circ} 18^{\prime} 55^{\prime \prime} \mathrm{W}\right)$, Mexico. The Compila lagoon is located on the western part of the system. It is a relatively small and shallow water body with several adjacent ponds.

\section{DISCUSSION}

In the original description of L. assiniboiensis, first described as D. intermedius, Anderson \& Fabris (1970) compared it with several other regional North American forms, but ignored L. cuauhtemoci. The type material of Leptodiaptomus assiniboiensis was reviewed almost three decades later by Grimaldo et al. (1998), who compared it with specimens from the state of Mexico, central Mexico. These authors determined the occurrence of L. assiniboiensis in Mexico and recognized it as a form closely related to L. cuauhtemoci. However, due to the lack of type material of the latter species, they suggested only a possible synonymy. The paratype specimens of L. assiniboiensis were examined later on by us and compared directly with specimens of $L$. cuauhtemoci from the type locality. The morphological details of the most relevant taxonomical features (i.e. structure of male and female fifth legs, details of the right male antennule, body proportions) were evaluated in order to find possible differences between $L$. assiniboiensis and L. cuauhtemoci, with negative results, even the size ranges being similar. L. assiniboiensis is therefore considered here to be conspecific with L. cuauhtemoci. According to the priority principle of the International Code of Zoological Nomenclature, the name $L$. cuauhtemoci, published in 1941, is valid for both, $L$. intermedius and L. assiniboiensis, published in 1970 and 1971, respectively. Hence, they are designated here as junior objective synonyms of this species, and a further comparison is made between the two valid species considered, L. cuauhtemoci and L. siciloides.

Leptodiaptomus cuauhtemoci and L. siciloides differ in several important characters both in males and females. This supports the idea that $L$. cuauhtemoci is a separate, valid species, not a synonym of $L$. siciloides, as suggested by previous workers. Differences distinguishing L. cuauhtemoci from $L$. siciloides are recognizable in both females and males, as follows:

Female: There were no differences in size. In $L$. cuauhtemoci, the lateral margins of pedigers 4 and 5 are almost straight showing the same dorsal width, while both taper posteriorly in L. siciloides, pediger 5 being narrower than pediger 4 (see Silva-Briano \& SuárezMorales, 1998, Figs 34, 47). The lateral spiniform processes on the genital somite are broader-based in $L$. cuauhtemoci (a character previously noted by OsorioTafall, 1941) than they are in L. siciloides (see SilvaBriano \& Suárez-Morales, 1998, Figs 37, 51). The right process on the genital somite of $L$. cuauhtemoci bears a large, broad-based spine pointing outwards in $L$. cuauhtemoci, whereas this structure is smaller, narrowbased, and directed backwards in L. siciloides (see Silva-Briano \& Suárez-Morales, 1998, Figs 37, 51).

The genital field is different in both species. In specimens of L. cuauhtemoci from Aguascalientes and from the type locality, the genital opening is proximally rounded, with an inner medial longitudinal column, and lateral lappets directed diagonally inwards (Fig. 23). In $L$. siciloides the upper margin of the genital opening is straight, the general structure is different, and lappets are directed posteriorly (Fig. 30).

Fifth leg endopods are one-segmented in both species, and have about the same relative length. However endopods in L. cuauhtemoci bear two large, broad, subterminal setae of about the same size (Fig. 12); these structures are differently built in L. siciloides, one being at least 2 times longer than the other, and both are relatively small (see Wilson \& Yeatman, 1959, Fig. 29.79c). Exopod 1 of L. siciloides 1.1 times shorter than exopod 2 vs 1.2 in L. cuauhtemoci. The inner margin of the claw is armed with a short row of low teeth on the middle margin in both cases, the row is relatively longer in L. siciloides. Exopod 3 is clearly distinct from exopod 2 in L. siciloides, represented by one long spine; the usual adjacent spine is less than half the length of the exopodal spine (Wilson \& Yeatman, 1959, Fig. 29.79 c). In L. cuauhtemoci the exopod 3 and the lateral spine of the second exopodal segment are both relatively thicker and of about the same size (Fig. 22).

Male: As in the females, there were no differences in size, but the body of the male L. cuauhtemoci is slenderer than that of $L$. siciloides, and the wings of pediger 5 are clearly more developed in L. cuauhtemoci as shown by Silva-Briano \& Suárez-Morales (1998, Figs 27, 43). In L. siciloides, urosomite 1 (genital somite) is smooth, while in L. cuauhtemoci it shows a fringe of minute spinules along the posterior margin; the fringes of spinules on the dorsal surface described for L. cuauhtemoci are quite reduced in L. siciloides, which shows an irregular, much lighter pattern. The spinules grouped along the posterior margin of this urosomite are relatively large in L. cuauhtemoci; in L. siciloides, these groups have quite short spines. These differences were noted previously by Osorio-Tafall (1941).

The modified right antennules of both species differ in several relevant details. The spines on segments 10 and 11 are relatively longer in $L$. siciloides, the former reaching half the length of segment 12 , and the latter reaching the level of the proximal portion of segment 14 (Fig. 26). In L. cuauhtemoci, the spine on segment 10 reaches the distal end of succeeding segment 11, whose spine barely reaches the distal end of segment 12 (Figs 
$4,15)$. The same spines show a different size pattern in both species. They are subequal in length (11/10 length ratio: 1.06 in specimens of the type locality, 1.3 in specimens from Aguascalientes) in L. cuauhtemoci (Figs 4, $15)$, whereas in L. siciloides the spine on segment 11 is over 1.5 times larger than that of segment 10 (Fig. 26; Wilson \& Yeatman, 1959, fig. 29.79e).

The spiniform extension of the right male antepenultimate antennular segment is straight along the shaft and bent only at the tip in L. siciloides (Fig. 27) while in L. cuauhtemoci it is bent from its middle portion (Fig. 17). Moreover, the inner margin of this process is strongly convex in L. cuauhtemoci and is slightly concave in L. siciloides (see Fig. 27). The process length/next segment length ratio is 1.6 in $L$. siciloides and 1.9 in $L$. cuauhtemoci.

A large coxal spine is present on the right fifth leg of L. siciloides, while it is absent in L. cuauhtemoci (Fig 11; see Silva-Briano \& Suárez-Morales, 1998, Figs 30, 45). The basis of the left fifth leg is relatively smaller in L. cuauhtemoci (26\% of basis+exopod total length) than it is in L. siciloides $(43 \%)$. Marsh $(1907,1929)$ stated that in L. siciloides the male right fifth leg bears a quadrangular hyaline appendage on the inner distal half of the first segment of the endopodite (see Fig. 29); in $L$. cuauhtemoci this process is not quadrangular, but clearly anvil-shaped, with a small posterior protuberance at the base of the process (Fig. 20; see Figs 30, 45 of Silva-Briano \& Suárez-Morales, 1998) which is absent in L. siciloides. This difference was already noticed by Osorio-Tafall (1941). The shape of this structure appears to be quite the same when viewed under the light microscope; this could be a factor of confusion between both the species for untrained observers.

Marsh (1929) described L. siciloides as having the right endopod much shorter than the first segment of the exopodite. This is true also for L. cuauhtemoci, but the structure of the right endopod differs in both species: in L. cuauhtemoci it has a patch of short hair-like setules from its middle portion to the tip (Fig. 19); in L. siciloides the structure is naked or lightly setulated (see Fig. 33 of Silva-Briano \& Suárez-Morales, 1998). The lateral seta of the right leg exopod 2 is slender and relatively small in L. siciloides, representing about $1 / 3$ of the second exopod length, or even less, as illustrated by Marsh (1907) and Wilson \& Yeatman (1959). In $L$. cuauhtemoci this seta is broader and relatively longer (ca. 1/2 of the second exopod length). This difference was also reported by Osorio-Tafall (1941). In L. siciloides this structure is inserted on the distal third of bearing segment (Fig. 28) whereas it is at about midlength in L. cuauhtemoci (Fig. 21).

The terminal claw of the exopod of the left fifth leg is broad, and its tip is rounded in L. cuauhtemoci from Aguascalientes and from the type locality (Figs 11, 21; Fig. 45 of Silva-Briano \& Suárez-Morales, 1998). The corresponding structure is slenderer, and with an acute tip in L. siciloides (Fig. 28). As described above, the claw has an inner hyaline furrow-like lamella not present in L. siciloides. The lateral spine on the second exopodal segment is slightly curved in L. siciloides, whereas it is strongly curved in L. cuauhtemoci.

The new specimens of $L$. cuauhtemoci are designated as neotypes following the conditions stated in the ICZN art. 75(i,ii). The new synonymy derived from the taxonomical analysis of these three species suggests a wide distributional range of $L$. cuauhtemoci, including several states of central Mexico (Aguascalientes, Mexico, and Morelos), and now the west-central area of Canada (Saskatchewan). It is expected that the distributional range of this species will include northern Mexico and the United States. It is suggested also that some of the North American records of L. siciloides could correspond to L. cuauhtemoci. The genus Leptodiaptomus, of Nearctic affinity, includes several species which most probably radiated southwards and reached central Mexico (Elías-Gutiérrez et al. 1998).

\section{ACKNOWLEDGEMENTS}

We gratefully acknowledge the valuable collaboration of Guadalupe Nieto, ECOSUR-Tapachula, who kindly helped us using the institutional SEM equipment. Chad Walter, NMNH-Smithsonian Institution, efficiently transacted the loan (reg. 420247, 311FY-1998) of USNM specimens. We received appealling comments and relevant literature from Janet W. Reid. The comments of the reviewers improved the quality of this work.

\section{REFERENCES}

Anderson, R.S. \& G.L. Fabris. 1970. A new species of diaptomid copepod from Saskatchewan with notes on the crustacean community of the pond. Can. J. Zool., 49: 49-54.

Anderson, R.S. 1971. A nomen novum to replace the junior homonym, Diaptomus (Leptodiaptomus) intermedius Anderson and Fabris, 1970. Can. J. Zool., 49: 133.

Balcer, M.D., N.L. Korda \& S.I. Dodson. 1984. Zooplankton of the Great Lakes; a guide to the identification and ecology of the common crustacean species. University of Wisconsin Press. Madison: $235 \mathrm{pp}$.

Dussart, B.H. \& D. Defaye. 1995. Introduction to the Copepoda. In: H. Dumont (Ed.), Guides to the identification of the macroinvertebrates of the continental waters of the world. SPB Academic Publishing, Amsterdam: 277 pp.

Elías-Gutiérrez, E., E. Suárez-Morales \& B. RomanoMárquez. 1999. A new species of Leptodiaptomus (Copepoda, Diaptomidae) from Northwestern Mexico with comments on the distribution of the genus. J. Plankton Res., 21(4): 603-614.

Grimaldo-Ortega, D., M. Camacho, M. Elías-Gutiérrez \& J. Ciros-Pérez. 1998. Additions to Mexican freshwater copepods with the description of the female of Leptodiaptomus mexicanus (Marsh). J. Mar. Syst., 15(1-4): 381-390.

Light, S.F. 1938. New subgenera and species of diaptomid copepods from the inland waters of California and Nevada. Univ. Calif. Publ. Zool., 43: 67-78.

Marsh, C.D. 1907. A revision of the North American species of Diaptomus. Trans. Wisc. Acad. Sci. Arts Lett., 15: 381516. 
Marsh, C.D. 1929. Distribution and key of the North American copepods of the genus Diaptomus, with the description of a new species. Proc. U.S. Nat. Mus., 75: 1-27.

Osorio-Tafall, B. 1941. Diaptomus cuauhtemoci nov. sp. de la mesa central de México (Copepoda, Diaptomidae). Ciencia, 2: 296-298.

Reid, J.W. 1990. Continental and coastal free-living Copepoda (Crustacea) of Mexico, Central America and the Caribbean region. In: D. Navarro \& J.G. Robinson (Eds), Diversidad Biológica en la Reserva de la Biosfera de Sian Ka'an, Quintana Roo, Mexico. CIQRO/University of Florida: $175-213$.

Silva-Briano, M. \& E. Suárez-Morales. 1998. Copepoda Calanoida (Crustacea) of Aguascalientes State, México. Scientia Naturae, 1: 37-68.

Received: December 1999

Accepted: February 2000
Suárez-Morales, E. \& J.W. Reid. 1998. An updated list of the free-living freshwater copepods (Crustacea) of Mexico. Southwest. Nat., 43(2): 256-265.

Suárez-Morales, E., J.W. Reid, T.M. Iliffe \& F. Fiers. 1996. Catálogo de los copépodos (Crustacea) continentales de la Península de Yucatán, México. CONABIO/ECOSUR. México: 296 pp.

Wilson, M.S. \& H.C. Yeatman. 1959. Free-living Copepoda. In: W.T. Edmonson (Ed.), Ward's \& Whipple's Freshwater Biology. John Wiley \& Sons, Inc. New York: 735-861.

Wilson, M.S. 1954. A new species of Diaptomus from Louisiana and Texas with notes on the genus Leptodiaptomus (Copepoda, Calanoida). Tulane Stud. Zool., 2(3): 51-60. 